\title{
A Study on Large-Class Teaching Strategies in Listening for English Major on Web-Based Autonomous Learning
}

\author{
Rui Huang \\ School of Foreign Languages Jimei University \\ Xiamen, China \\ E-mail: huangrui@jmu.edu.cn
}

\begin{abstract}
The effectiveness of teaching university students in large-class has been debated since 1924. In China, the popularity of higher education in 1999 makes overwhelming rise to school-age youth to enter universities; hence, large-class teaching even has become an important form of curriculum for English major. However, previous research literature reveals that the main mode of large-class teaching is giving lectures and doing interactive teaching in writing and some selected or optional courses, but less in discussing in teaching of listening. Listening is a skill course. How to guarantee the teaching quality and students' interest in learning the skill in a large class; how to consciously improve students' autonomous learning, and the professional listening class teaching on webbased autonomous learning strategy give many inspirations. This paper analyzes two different classes $(\mathrm{CA}$ and $\mathrm{CB})$ with different teaching methods and strategies via questionnaire survey. We found out in large class web-based autonomous listening teaching, correctly and properly applied learning strategies will greatly achieve listening performance, develop and cultivate students listening abilities. It also explores the feasibility and effectiveness of a large-class in teaching listening based on web-based autonomous instruction.
\end{abstract}

Keywords-web-based autonomous instruction; strategy; large-class; teaching of listening; English major

\section{INTRODUCTION}

The popularity of higher education in 1999 in China, have made a huge increase in the number of school-age youth to enter in tertiary education or universities; large-class teaching has become the important form of higher education. Although classroom teaching in English major has its specific goal, only small-class teaching reaches interaction between teachers and students, or students to students to activate classroom atmosphere so as to achieve the purpose of language teaching - communication. It appears that large classes are here to stay due to the rising enrollment during the past decade and the declining funds for over-built large colleges and universities in recent years [1]. University administrators find large classes economically advantageous [2]; however, many schools face the dilemma of large-class teaching for English majors. For instance, a foreign language school in a university only has 105 students in four classes

Funding: The study has been supported by the Science Foundation of Fujian Province. Item No. are JB2015B260 and JA13690S entitled A Research on M-learning in Large Class Teaching of English Major in Higher Education. five years ago, but it increased up to 230 students in eight classes recent years. Because of the limitation for a variety of reasons, the education resource allocation and the growth of teachers could not cope with the growing number of students So, great impact has affected the traditional small-class teaching mode for English major. At present, some specialty skill courses such as listening and reading classes have contained more than 75 students to have class together [3], and some optional courses such as Linguistics, Literature, Language Testing and Academic Writing etc have more than 120 students in one class in a university [4]. To English as a Foreign Language or EFL teaching, it is quite not normal. In order to solve such problems, many universities have to change teaching mode from face-to-face teaching into webbased autonomous instruction. On the one hand it can solve the dilemma that lack of teachers and facility for teaching face-to-face, on the other hand, task-based and learnercentered teaching mode let students can widely select listening materials while more and more authentic materials can be accessed through internet.

The paper emphasizes the empirical study of teaching a large-listening class by analyzing the listening status of English major students and the demerits of and solutions to such through questionnaire survey, with the integration of theories and principles of listening and web-based autonomous study to explore the feasibility and effectiveness of large-class scenario in teaching listening. The purpose is to offer guidance to EFL teaching especially in skill courses and to recommend strategies and solutions to solve the problems caused by large-class teaching.

\section{LITERATURE REVIEW}

This section is a review of studies and publications on large class teaching of listening using web-based instruction. There is no related literature we can search about large class teaching of listening using web-based instruction for English major students outside China. In western countries, Most of time small class teaching method is a classical and model methodology let other countries follow. About large class teaching, the research of Hall [5] documents the distances at which people interact in our culture. The upper limit of a comfortable social distance is 12 feet. Spatial separations up 
to 25 feet are reserved for certain "public" communications but are not conducive to interpersonal interaction. Obviously distances between professors and students in large classrooms frequently exceed both limits, with noticeable effects on the communication climate [6]. Gleason also mentioned in large class we can make space "small". Another study by Hayes [7] mentioned to remember students' names is very important even in large class teaching. The prior related study in China, in Feng [8] research results revealed that large class teaching can adopt the same communicative theory as we adopt in small class teaching such as teachers may come to class a few minutes earlier or enlarge the circle as we mention above. Zhang [9] focused on analysis of large-class teaching strategies and problems for English major but did not connect with course subject, Li [10] and Xiong [11] emphasized on College English teaching instead of students major in English, Chang[12] and Feng [8] were keen on large-class teaching strategies but not under web-based autonomous instruction.

Meanwhile, Ge [13] in 2008 made an experimental study to analyze the result and found out after using web-based autonomous study, the motivation and interest of the students actively learning listening have improved a lot. The findings suggested that web-based autonomous study needs under teachers instruction, in this way, those relatively poor students easily were ignored in traditional class would be paid more attention to. Likewise, $\mathrm{Li}$ [10] conducted a survey about autonomous learning ability. The results revealed there was significant difference before experiment $($ Mean=3.18) and after experiment (Mean=3.90) in teaching of College English listening and speaking. However, her study was based on multimodal discourse analysis theory that is quite different with web-based instruction.

On the other hand, a study by Xiao [14] in 2006 revealed if we improved learning strategies, it could also effectively improved students learning listening effectively under webbased autonomous study. Another study by Li [15] about web-based autonomous listening learning strategies revealed that the new teaching model is superior in some external/internal factors such as questioning, cooperation, risk orientation, self- monitoring, auditory representation, selective attention, environment, but defective in interest, reinforcement, autonomous employment of extra-curriculum resources, preview and task difficulty.

This study is similar to the studies of Ge [13], Xiao [10] and $\mathrm{Li}$ [15] done by EFL teachers in China. However, it is also different because the study was conducted to university English major students in Jimei University with overall higher level of English skills.

\section{METHODOLOGY}

\section{A. Instrumentation}

Based on the objectives of this study, the most appropriate methods are test paper and questionnaire.

For test paper method, an entrance examination served as a pretest for $\mathrm{CA}$ and $\mathrm{CB}$ students when they entered the school. The same test as posttest was given to them after one semester. The pretest-posttest follows the College English Test Band 4 for listening comprehension which included short conversation and two long conversations and listening passages and the Test for English Major Grade for News Broadcasting. The total mark is 70 .

The questionnaire method was conducted to both $\mathrm{CA}$ and $\mathrm{CB}$ after one semester. It was divided into two parts. The first part, which is an excerpt from the study of Wen Quifang [16] is general information that focused on the participants' listening attitude with Likert-type scale. The second part, taken from O'Malley\& Chamot study on Metacognitive Cognitive Strategies and Taxonomies of Social, Emotional Strategy [17] simply emphasized listening strategies.

\section{B. Research Procedure}

In this experimental study, the researcher conducted had undergone the following procedures:

1) Randomly selected two classes, Class A and Class B; $C A$ acted as control group while $C B$ was an experimental group;

2) At the beginning of semester, we had a test (i.e. pretest) to evaluate students' level both for $C A$ and $C B$;

3) After one semester teaching with different model, $C A$ with conventional listening while $C B$ with web-based autonomous listening learning under the teacher's instruction, we had a test (posttest) again in order to find difference;

4) Both $C A$ and $C B$ have finished the survey of questionnaire;

The mean score of students in $\mathrm{CA}$ and $\mathrm{CB}$ were interpreted using the t-test or direct difference method. The rating with differentiated verbal description will decide the extent of the difference in two samples (CA and CB), items, and strategies described as follows:

- very significant

- moderate difference

- less significant

- no significant difference

\section{Method of Analysis}

The results of the experiment in $\mathrm{CA}$ and $\mathrm{CB}$ were analyzed and interpreted using mean and the t-test rating. The students performance in the pretest (entrance test) and posttest (test after one semester) were analyzed using the description statistics, while their listening attitude towards listening were evaluated using t-test. For listening strategies for both $\mathrm{CA}$ and $\mathrm{CB}, \mathrm{t}$ value and Mean Difference (MD) were used to analyze and interpret data.

\section{PRESENTATION, ANALYSIS, AND INTERPRETATION OF DATA}

This part of the study presents analysis and interpretation of the data taken from the tests (pretest and posttest) and questionnaire conducted by the researcher on $\mathrm{CA}$ and $\mathrm{CB}$. 
TABLE I. STATISTICAL DESCRIPTION OF T-TEST (ENTRANCE EXAMINATION) FOR CLASSES CA AND CB

\begin{tabular}{|l|l|c|c|c|l|}
\hline \multirow{2}{*}{ Class No. } & \multicolumn{5}{|c|}{ Statistical Description } \\
\cline { 2 - 3 } & Mean & $\boldsymbol{S D}$ & $\boldsymbol{t}$ & $\boldsymbol{N}$ & Sig.(2-tailed) \\
\hline $\mathrm{CA}$ & 49.163 & 5.121 & & 70 & 0.000 \\
\hline $\mathrm{CB}$ & 52.072 & 7.972 & $-2.561^{*}$ & 71 & 0.000 \\
\hline
\end{tabular}

"Table I" shows the statistical description of the t-test for the two classes during entrance examinations. Before the experiment, an entrance test for both CA and CB using SPSS 19.0 was conducted to test the mean difference between two independent samples. It reveals a mean of 48.581 for CA and a mean of 47.932 for $\mathrm{CB}$ or a df of 69 for $\mathrm{CA}$ and a df of 70 for $\mathrm{CB}$. There is no significant difference between $\mathrm{CA}$ and $\mathrm{CB}$. This means the English level of $\mathrm{CA}$ and $\mathrm{CB}$ is the almost same.

TABLE II. Statistical Description OF Post TeSt (After EXPERIMENTAL STUDY) FOR CA AND CB

\begin{tabular}{|l|l|l|l|l|}
\hline \multirow{2}{*}{ Class No. } & \multicolumn{4}{|c|}{ Statistical Description } \\
\cline { 2 - 5 } & Mean & SD & $\boldsymbol{t}$ & $\boldsymbol{d} \boldsymbol{f}$ \\
\hline CA & 48.581 & 5.283 & \multirow{2}{*}{0.641} & 69 \\
\hline CB & 47.932 & 6.621 & & 70 \\
\hline
\end{tabular}

"Table II" shows the mean of CA which is 49.163 and the mean of $\mathrm{CB}$ which is 52.072. There is a significant difference between $\mathrm{CA}$ and $\mathrm{CB}$. The mean of $\mathrm{CB}$ is higher than $\mathrm{CA}$ by 3 . $\mathrm{T}$ value is bigger than the critical value 1.960 $(\mathrm{N}>120)$, while $\mathrm{p}<0.05$. This means there is a significant difference after one semester study between $\mathrm{CA}$ and $\mathrm{CB}$. From the result of the post-test, we also know there is a big gap between high score and low score. The study also reveals after one semester of study, both $\mathrm{CA}$ and $\mathrm{CB}$ made great progress.

TABLE III. STUDENTS' LEARNING ATtITUdE TOWARdS Listening USING QUESTIONNAIRE

\begin{tabular}{|c|c|c|c|c|c|c|}
\hline \multirow{2}{*}{$\begin{array}{c}\text { Class } \\
\text { No. }\end{array}$} & \multicolumn{6}{|c|}{ Statistical Description } \\
\hline & Mean & $t$ & Mean & $t$ & Mean & $t$ \\
\hline CA & 3.112 & \multirow{2}{*}{-2.348} & 3.298 & \multirow{2}{*}{-1.832} & 2.974 & \multirow[b]{2}{*}{1.748} \\
\hline $\mathrm{CB}$ & 2.922 & & 3.181 & & 3.194 & \\
\hline
\end{tabular}

"Table III" presents the learning attitude of classes CA and $\mathrm{CB}$ after one semester's study. The table reveals there is $0.19(3.112-2.922)$ mean difference $(M D)$ between CA and CB in metacognitive; 0.117(3.298-3.181) in cognitive; and 0.22 in social/affective aspect. The first part of the questionnaire also shows $74.3 \%$ students in CA and $75.1 \%$ in $\mathrm{CB}$ believe that the more listening practice is kept, the higher ability of listening they could achieve. It also shows $88.9 \%$ in $\mathrm{CA}$ and $90.1 \%$ in $\mathrm{CB}$ think listening course is very important and they anticipate to having listening classes in a multimedia classroom.
However, "Table III" also shows there are significant differences between $\mathrm{CA}$ and $\mathrm{CB}$ with the use of listening strategies reflected in the results of part two questionnaire. $\mathrm{CB}$ has lower frequent usage of listening strategies compared to $\mathrm{CA}$. This means students in $\mathrm{CB}$, when left in an autonomous study without teacher's supervision, used less listening strategies. Three kinds of strategies use frequency from high to low order are cognitive, social/affective, and metacognitive strategies. $\mathrm{CB}$ has a $t$ value of -2.348 ; therefore, the meta-cognitive strategy between $\mathrm{CA}$ and $\mathrm{CB}$ has a significant difference. As teachers often emphasized cognitive strategies, the frequency of using them are much higher than the other two. In comparing other strategies used in $\mathrm{CA}$ and $\mathrm{CB}$, it reveals meta-cognitive strategies were less used in CB. This reflects the teacher neglected using them when he guided students in autonomous listening practice.

TABLE IV. DIFFERENCES ON LISTENING STRATEGIES FOR CA AND CB USING QUESTIONNAIRE

\begin{tabular}{|l|l|l|l|}
\hline $\begin{array}{c}\text { Listening } \\
\text { strategies }\end{array}$ & \multicolumn{1}{|c|}{ Sub-strategies } & \multicolumn{1}{|c|}{$\boldsymbol{M}$} & \multicolumn{1}{c|}{ MD } \\
\hline metacognitive & preview & $-2.327^{*}$ & -0.405 \\
\cline { 2 - 4 } & self-management & $-2.178^{*}$ & -0.243 \\
\cline { 2 - 4 } & selective attention & $-3.059^{* *}$ & -0.289 \\
\cline { 2 - 4 } & imagination & $-2.006^{*}$ & -0.345 \\
\hline cognitive & migration strategies & $-2.700^{* *}$ & -0.261 \\
\cline { 2 - 4 } & take notes & $-2.094^{*}$ & -0.156 \\
\hline social/affective & cooperative learning & $2.038^{*}$ & 0.280 \\
\hline
\end{tabular}

In the course of the experimental study and before class starts, each strategy in the questionnaire has symbols: lesson preparation (S3), self-management (S2, S5, S6, S7, S16) and selective attention (S9, S10); note-taking (S31, S32, S33), imagination (S26) and migration strategies (S20, S21, S22, S41). [17]

"Table IV" presents there are significant differences between $\mathrm{CA}$ and $\mathrm{CB}$ on three items of metacognitive strategies: self-management with $-2.178 \mathrm{t}$ value, selective attention, $-3.059 \mathrm{t}$ value; and imagination, $-2.006 \mathrm{t}$ value. Among the three strategies, selective attention strategies show it has the most significant difference with a t value of 3.059. Before class start, each strategy was given symbols in the questionnaire: lesson preparation (S3), self-management (S2, S5, S6, S7, S16) and selective attention (S9, S10).

The table also shows significance differences on three items: note-taking, imagination, and migration. This means both $\mathrm{CA}$ and $\mathrm{CB}$ students do not like to take down notes. In $\mathrm{CA}$, the teacher always mentions taking notes when necessary. In $\mathrm{CB}$, students have not developed the habit of note-taking as they think listening is just to understand what the speaker (or listening material) says. While listening, they rarely pay special attention to the grammatical features of sentences and less attention to related knowledge and cultural background of the material. In the social/affective item, CB got significance difference. Students in CB are 
encouraged to ask and answer questions, discuss them with their classmates, and do activities like pair work.

To reinforce questionnaire data on listening strategies, an interview conducted by the researcher with freshmen students reveal they knew little about studying strategies in university. Specifically, it also reveals that some CB students have no idea how to do an autonomous study; they do not know how to follow the teacher's instruction; and they do not realize the importance of selective strategies. For CA students who utilized the autonomous classroom, the interview shows $68.9 \%$ seldom practice independently and actively. In both $\mathrm{CA}$ and $\mathrm{CB}, 18.9 \%$ of students like to take notes in class, while $43.1 \%$ does note-taking occasionally, and $24.3 \%$ does not take note at all.

TABLE V. DIFFERENCES IN T-TeSt BETWEEN HIGH AND LOW SCORE/LEVEL STUDENTS IN ClASS B (CB) USING QUESTIONNAIRE

\begin{tabular}{|l|l|l|c|}
\hline \multicolumn{1}{|c|}{ Listening strategies } & \multicolumn{1}{|c|}{ Sub-strategies } & \multicolumn{1}{c|}{$\boldsymbol{M}$} & \multicolumn{1}{c|}{} \\
\hline metacognitive & projecting & $2.257^{*}$ & 0.523 \\
\cline { 2 - 4 } & self-management & $2.371^{*}$ & 0.430 \\
\cline { 2 - 4 } & self-assessment & $2.219^{*}$ & 0.607 \\
\hline \multirow{2}{*}{ cognitive } & migration strategies & $2.039^{*}$ & 0.343 \\
\cline { 2 - 4 } & take notes & $2.056^{*}$ & 0.743 \\
\hline social/affective & solve problems & $2.067^{*}$ & 0.470 \\
\hline
\end{tabular}

Thirteen high and low score/level students were chosen separately [18] in CB to analyze the strategies they used.

"Table V" shows there are significance differences in six items. In metacognitive strategy, self-management has the most significant difference with t-value of 2.371. This means high score/level students are perceived as academically good that study more independently; they prefer to follow the teacher's requirements; and accomplished learning tasks required by the teacher. In cognitive section, migration strategy's t-value is 2.039 . This shows that academically good students like to take notes while they listen, but the data also shows the frequency of using this strategy is not very significant. In social/affective aspect, solving problems has a t-value of 2.067. This indicates that high level students in CB have good study habits; they are good at solving problems and discussing them with their classmates or teachers. This data has the same results in Wen Qiufang's study [19].

The data also indicates that low level students, when they encounter problems, lack the habit of solving them on time. Autonomous study is like a self-study situation and most of the time, learners themselves guide their own studies. Although the teacher gives students the task to finish it in class as some of them are ashamed to ask questions or to clarify when they encounter difficulties.

\section{SUMMARY AND CONCLUSION}

\section{A. Summary}

This study conducted experimental teaching strategies in two big listening classes using the traditional method and the autonomous web-based instruction to discover the effectiveness of these strategies on the listening skills and attitudes of students.

The subjects/participants were the 141 freshmen students who were officially enrolled as English major course. They were divided into two big listening classes: $\mathrm{CA}$ and $\mathrm{CB}$.

$\mathrm{CA}$ is composed of 70 students that adopted the traditional teaching mode. This means lectures were given by the teacher in language laboratory. They occasionally used the autonomous-learning classroom in specified time without the teacher's instruction.

$\mathrm{CB}$ has 71 students where student-centered teaching mode was conducted using web-based autonomous instruction approach. This means that on odd weeks (Week 3, 4,5 , for example), lectures were given and classes were held in the language lab and on even weeks (Week 2, 4, 6, etc.), listening classes were conducted in web-based autonomouslearning classroom.

The study reveals that teaching listening in a large class using web-based autonomous instruction and learning strategies, when correctly and properly applied, not only develops and cultivates students' listening abilities, but also contributes in achieving great listening performance.

Statistical data results after show there are significant differences between the learning achievements of the two classes of students after using different teaching mode. The English levels of CA and CB were the same when they entered the school (see Table 1), after one semester of training. There are significant differences between $\mathrm{CA}$ and CB (see TABLE III and TABLE IV) in terms of their listening strategies. The result in TABLE V shows high level or academically good performing students and low level or academically poor performing students in $\mathrm{CB}$ can reach different achievements if they used learning strategies properly. The results also reflected on how teachers could teach listening in an effective way and what should they pay more attention to while teaching listening.

\section{B. Conclusion}

Based on the results of statistical data, the study revealed that Web-based autonomous teaching suit the large-scale class teaching to overcome the shortage of teachers and educational funding. It also helped in developing learners' autonomous learning habit and improving their listening abilities if students could use the strategies effectively. The study also discovered that teaching listening in a large class using web-based autonomous instruction and learning strategies, when correctly and properly applied, not only develops and cultivates students' listening abilities, but also contributes in achieving good listening performance. Webbased autonomous teaching is a kind of teaching mode. It is not used in place of classroom teaching or as guide for 
teachers. It is a developmental trend that reflects and responds to the needs of education. It also puts to a higher standard the requirements for teacher's qualification techniques and capacity to teach. Large-class English teaching of listening using web-instruction stressed mutuality, coordination, and influence. It gave importance in developing the students' creative thinking and ability to practice. In the process of teaching a large class using autonomous instruction, there are still problems or issues that need deeper thinking and immediate attention such as maintaining the students' interest in their studies, improving the quality of teaching, creating an environment good for large-class learning. The merits or demerits of two different teaching modes can improve students listening ability, while web-based autonomous study under the teacher's guidance can promote the competence quicker and more effectively. The study revealed three significant differences first difference is about listening strategies of two classes of students using teaching-learning approaches, the traditional and web-based instruction. Second significant differences are between the learning achievements of the two classes of students after using different teaching mode traditional or control group and web-based or experimental group instruction. Third significant differences are also between the listening learning strategies of the poor and outstanding students in CB. For the outstanding students in web-based autonomous instruction class can achieve high grade after one semester study.

\section{REFERENCES}

[1] Lewis, G. K., Woodward, P., \& Bell, J. Teaching business communication skills in large classes. Journal of Management Education, 1988, 1, pp65-86.

[2] Crull, S. R., \& Collins, S. M. Adapting traditions: teaching research methods in a large class setting. Teaching Sociology, 2004,2, pp206212

[3] Huang Rui. An empirical study on large-class teaching strategies of listening teaching in English major on Web-based autonomous learning. Journal of Jimei University, 2013,4, pp112-115.

[4] Chang Jiying. An empirical study of problems and coping strategies in the teaching of English writing in enlarged classes. Foreign Language and Their Teaching, 2003,3, pp38-41.

[5] Hall Edward. The Hidden Dimension. New York: Anchor Books, Doubleday. 1966

[6] Gleason M. Better Communication in Large Course. College Teaching, 1986,1,pp20-24.

[7] Hayes, D. (1997). http://www.classmates.com/people/DominekeHayes/552745791

[8] Feng Meina. The Strategies of teaching listening for English major in large class. Journal of Southwest Agricultural University, 2012,7, pp97-100

[9] Zhang Jun Analysis of teaching strategies and problems under condition of large class teaching for English major. Journal of Language and Literature Studies, 2011,2, pp136-138.

[10] Li Hong. Application of the multimodal discourse analysis theory to the teaching of College English listening and speaking, IERI Procedia, 2012,2, pp319-324.

[11] Xiong Hui. The Research Based on Net-work Large Class Teaching Mode for College English. Foreign Language and Their Teaching. 2006,11, pp29-31
[12] Chang Junyue \& Ni Chunyan. Feasibility study on large-class language teaching for major English. Foreign Language and Their Teaching, 2003,6, pp25-28.

[13] Ge Shili. An empirical study of College English listening teaching reformation under the framework of autonomous learning Journal of Nanchang University. 2008,6, pp123-126.

[14] Xiao Jing. How to improve the efficiency of listening of autonomous learners through strategy training under online multimedia environment. Computer-Assisted Foreign Language Education, 2006,2, pp74-77.

[15] Li Qinghua. A Study of Web - based Autonomous Listening Learning Strategy. Journal of Huazhong Agricultural University (Social Sciences Edition), 2006,5, pp125-131.

[16] Wen Qiufang. English learner strategies. Shanghai: Shanghai Foreign Language and Education Press,1996.

[17] O’Mally, J.M.\& Chamot, A.U. Learning strategies in second language acquisition. London: Cambridge University Press. 1990.

[18] Brown, James Dean. Criterion-referenced Language Testing. London: Cambridge University Press. 2002.

[19] Wen Qiufang Differences in Approach between Successful and Unsuccessful English learner. Foreign Language Teaching and Research. 1995,3, pp 61-66. 